\title{
Contributions to Study of the Antimicrobial Activity of Inula Viscosa Harvested in Boumerdes (Algeria)
}

\author{
Nadjiba CHEBOUTI-MEZIOU
}

\begin{abstract}
Our work consists of a phytochemical study, followed by an evaluation of the antimicrobial activity of bioactive substances (total polyphenol) of the Inula viscosa. Dosages of recorded total polyphenol are respectively $13.3 \mathrm{mg}$ EAG / 100g powder leaves EAG $8.15 \mathrm{mg} / 100 \mathrm{~g}$ powder for stems. These results indicate that the polyphenol content in the leaves is high relative to the rods. it appears that the strains Staphylococcus aureus and Enterobacter sp. are highly sensitive $(25 \pm 1.00 \mathrm{~mm}, 1.00 \mathrm{~mm} \pm 22)$ Escherichia coli (9 $.33 \pm 0.33 \mathrm{~mm}$ ), Bacillus thuringiensis (9.66 \pm 1.33 ), Pseudomonas aeruginosa (9.66 \pm 1.20$)$, Micrococcus sp. (10.66 $\pm 0.33 \mathrm{~mm})$ Aspergillus niger $(9.33 \pm 0.33 \mathrm{~mm})$ are sensitive while Candida albicans is highly sensitive $(15.66 \pm 1.76 \mathrm{~mm})$. It is found that the extract of these leaves antimicrobial effects on different strains tested except Klebsiella pneumoniae $(0 \pm 0 \mathrm{~mm})$ and Salmonella enterica $(0$ $\pm 0 \mathrm{~mm}$ ) or had not observed an inhibition zone goshawks disks, which shows the resistance of these strains. According to the observed diameter, the antimicrobial activity of the polyphenols from the extract of stems of Inula viscosa depends on the strain tested. It turned out that this extract has means antimicrobial effect on Staphylococcus aureus (14.33 $\pm 0.66 \mathrm{~mm})$, Enterobacter sp. (12.33 \pm $1.45 \mathrm{~mm})$, Bacillus thuringiensis (10 .66 $\pm 1.45 \mathrm{~mm})$ Micrococcus sp. $(9.33 \pm 0.33 \mathrm{~mm})$, Klebsiella pnoumoniae $(9.33 \pm 0.88 \mathrm{~mm})$ and Candida albicans $(8 \pm 1 \mathrm{~mm})$, which allowed us to infer that these bacteria are sensitive against strains of Escherichia coli $( \pm 00)$, Pseudomonas aeruginosa $(0 \pm 0)$ Salmonella enterica $(0 \pm 0)$ and Aspergillus Niger $(0 \pm 0)$ show no microbial activity. Crude extracts of plants are starting to have a lot of interest as a potential source of natural bioactive molecules. They are the subject of study for their possible use as an alternative for the treatment of infectious diseases and to protect food against oxidation.
\end{abstract}

Keywords - Antimicrobial effect, Inula viscosa and polyphenol..

\section{INTRODUCTION}

Medicinal plants are still the first tank of new drugs. They are considered essential raw material source for the discovery of new molecules necessary for the development of future drugs. [1] The study of the chemistry of plants is still a burning issue despite its age. This is mainly because the vegetable is an important source of immense variety of bioactive molecules. This plant material contains a large number of molecules that have multiple interests put to use in the food industry, in cosmetics and pharmacy. These compounds include, coumarins, alkaloids, phenolic acids, tannins, terpenes and flavonoids Polyphenols are gifted effect

Nadjiba CHEBOUTI-MEZIOU, Department of Biology, University of Boumerdes, Algeria (UMBB) Affiliation : Laboratory soft technology physicochemical recovery and biodiversity of multiple therapeutic benefits, they play a very important role, especially in the fight against cancer, cardiovascular disease and lipid peroxidation. Thereby explaining their wide use in the manufacture of drugs. They are also involved in the protection of plants against various microbial attacks (especially fungal) which may cause the loss of a large amount of vegetation [2]. Human traditions were treated with the plants they had at their disposal against minor illnesses, colds or coughs, or more serious, such as tuberculosis or malaria. Neither chance nor religion nor superstition that guided traditional medicine to use a plant rather than another. Certainly, it is the experience where gents appreciate the soothing and plants painkillers. They have developed the knowledge and use of medicinal plants aim to overcome suffering and improve the health of men. [3] Inula viscosa is an annual, herbaceous, glandular and viscous, with a strong odor. It can reach $50 \mathrm{~cm}$ to $1 \mathrm{~m}$ in height has very large heads with yellow flower at the top of the stem, the leaves are entire or dentate, acute, sinuate; the stem amplexicaul more widely; lance-shaped, fairly large flower heads in long pyramidal clusters. [4] .The work [5] reported that the aerial parts of Inula viscosa contain flavonoids, sesquiterpene acids and esters triterpenes. The roots contain many compounds: This is a widespread plant in northern Algeria throughout the mediterranean rim; rock gardens; scrubland; land; little wet clay and roadsides. In Algeria, this plant is used in folk medicine as an antipyretic in herbal teas or baths in the fight against malaria [5]. The aim of our study was to estimate the content of this plant species in these compounds core assets, polyphenols obtained in different parts of the plant and to evaluate the antimicrobial activity).

\section{MATERIAL AND METHODS}

\section{A. Plant material used}

The plant used was harvested at the beginning of April at the Dellys region in the forest Bouarbi in Boumerdes. 


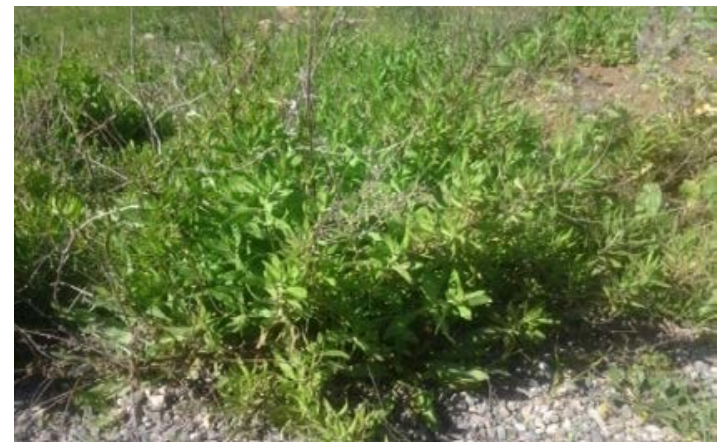

Fig. 1 : Inula viscosa in the forest of Bouarbi (Dellys)

\section{B. Methods used}

Drying the leaves and stems:

This study was conducted in order to lower the water content of leaves and stems harvested, and thus prevent spoilage reactions that may occur, to limit the proliferation of microorganisms. the harvested parts are dried in the open air and protected from light for two weeks

Grinding dried leaves and stems :

The leaves and stems are dried ground into fine powder using an electric grinder the powders obtained are stored away from moisture, in tightly closed glass jars .The ground material will be dry material will be used for the extraction of total polyphenols

Principle of solid / liquid extraction :

The solid / liquid extraction is a separation operation of extracting a solid component of a matrix that includes several by selectively transferring to a liquid phase. The solvent used in the present work and absolute methanol because methanol is the best extraction solvent for phenolic compounds. [6]

Retrieving excerpts:

After weighing the flask containing the crude polyphenol extract, it is filled into sterile glass pill boxes shaded and kept in a refrigerator at $4{ }^{\circ} \mathrm{C}$ until use.

Evaluation of the antimicrobial activity :

The technique used to evaluate the antimicrobial activity of the extract is the susceptibility or medium agar diffusion method using sterile disks .This method to determine the inhibitory activity of antimicrobial agent, by measuring the diameter the zone of inhibition around a disk impregnated with test extract .This method is widely used [7].

\section{RESUlTS AND DisCUSSION}

\section{A. Dry crude extracts yield}

After the extraction of phenolic compounds from the powdered Inula viscosa (stems, leaves) by maceration method in methanol, the yield of crude polyphenol extract is calculated from the mass of the extract before and after evaporation in relation to $10 \mathrm{~g}$ of plant powder. The extract obtained by evaporation has a gelatinous liquid appearance of a dark brown color.
TABLE I

Polyphenol Yield Of LeAVES AND Of SteMs INULA Viscosa

\begin{tabular}{l|c|c}
\hline Empty flask (g) & 157.930 & 179.506 \\
Flask + extract (g) & 161.671 & 177.778 \\
Extract (g) & 3.741 & 1.828 \\
YIELD \% & 37.41 & 17.28 \\
\hline
\end{tabular}

Comparing the polyphenol contents of both extracts we see that the highest value is present in the leaves (37.41\%) followed respectively rods $(17.28 \%)$. The comparison of different yields highlight the richness of the extracted phenolic compounds. The results obtained show that the yield of methanol extract of the leaves $(37.41 \%)$ is greater than that of the rods (17.28\%) (Fig. 2).

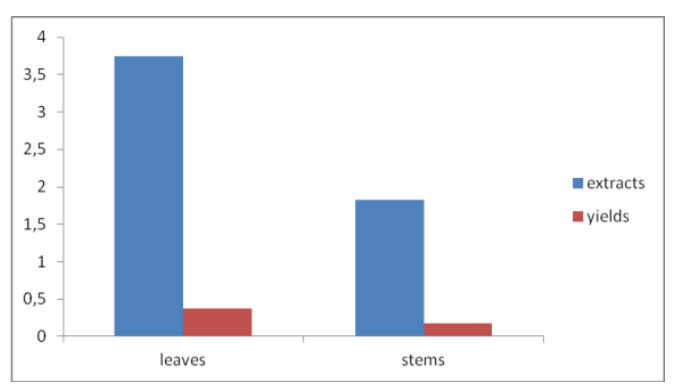

Fig. 2 : Yield (\%) in dry raw extracts of Inula viscosa

The results of this study showing that extracts of Inula viscosa are rich in phenolic compounds. Indeed, theyield is not relative then; it depends on the method and conditions under which the extraction was made other. This difference may be due to the nature of the plant material [8]. It varies the harvested organ; the period and mode of harvest. It is closely related to soil and climatic factors of the environment. The method of storage and packaging also influence performance [9]. On the other hand, some authors note that the method of extraction also affects the total content of polyphenols, flavonoids and antioxidant capacity [10].

\section{B. Evaluation of the antimicrobial activity of phenolic} compounds :

The evaluation of the antimicrobial activity of extracts from leaves and stems of Inula viscosa, is done by measuring the diameter of the inhibition zones (light area).

From these results, it appears that the strains Staphylococcus aureus and Enterobacter sp. are extremely sensitive (25 \pm 1.00 $\mathrm{mm}, 1.00 \mathrm{~mm} \pm 22)$ Escherichia coli $(9.33 \pm 0.33 \mathrm{~mm})$, Bacillus thuringiensis (9.66 \pm 1.33$)$ Pseudomonas aeruginosa (9.66 \pm 1.20), Micrococcus sp. (10.66 $\pm 0.33 \mathrm{~mm})$ Aspergelgillus niger $(9.33 \pm 0.33 \mathrm{~mm})$ are sensitive while Candida albicans is very sensitive $(15.66 \pm 1.76 \mathrm{~mm})$ of this sheet The extract from the leaves has antimicrobial effects on different strains tested except Klebsiella pneumoniae $(0 \pm 0$ $\mathrm{mm})$ and Salmonella enterica $(0 \pm 0 \mathrm{~mm})$ or had not observed an inhibition zone goshawks discs, which shows the resistance of these strains. 
TABLE II

Result Of The ANTIMicrobial Activity Of THe Polyphenol EXTRACt OF LEAVES INULA VISCOSE

\begin{tabular}{|c|c|c|c|}
\hline $\begin{array}{l}\text { Microbial } \\
\text { strain }\end{array}$ & $\begin{array}{l}\text { Average } \\
\text { (mm) }\end{array}$ & $\begin{array}{c}\text { Area } \\
\left(\mathrm{mm}^{2}\right)\end{array}$ & $\begin{array}{l}\text { Coefficient } \\
\text { inhibition }\end{array}$ \\
\hline Escherichia coli & $9.33 \pm 0,33$ & $\begin{array}{c}136.7 \\
3\end{array}$ & 1.36 \\
\hline $\begin{array}{c}\text { Bacillus } \\
\text { thuringiensis }\end{array}$ & $9.66 \pm 1,33$ & $\begin{array}{c}146.5 \\
7\end{array}$ & 1.46 \\
\hline $\begin{array}{l}\text { Pseudomonas } \\
\text { aeruginosa }\end{array}$ & $9.66 \pm 1,20$ & $\begin{array}{l}146.5 \\
7\end{array}$ & 1.46 \\
\hline Micrococcus sp. & $10.66 \pm 0.33$ & $\begin{array}{c}178.4 \\
9\end{array}$ & 1.78 \\
\hline $\begin{array}{c}\text { Salmonelle } \\
\text { enterica }\end{array}$ & $0 \pm 0$ & 0 & 0 \\
\hline $\begin{array}{c}\text { Staphylococcus } \\
\text { aereeus }\end{array}$ & $25 \pm 1.00$ & $\begin{array}{c}981.4 \\
7 \\
\end{array}$ & 9.81 \\
\hline $\begin{array}{c}\text { Klebsiella } \\
\text { pneumonias }\end{array}$ & $0 \pm 0$ & 0 & 0 \\
\hline $\begin{array}{c}\text { Enterobacter } \\
\text { sp. }\end{array}$ & $22 \pm 1.00$ & $\begin{array}{c}760.2 \\
6 \\
\end{array}$ & 7.60 \\
\hline $\begin{array}{c}\text { Aspergillus } \\
\text { niger }\end{array}$ & $9.33 \pm 0.33$ & $\begin{array}{c}136.7 \\
3 \\
\end{array}$ & 1.36 \\
\hline $\begin{array}{l}\text { Candida } \\
\text { albicans }\end{array}$ & $\begin{array}{c}15.66 \pm 1.7 \\
6\end{array}$ & $\begin{array}{c}385.2 \\
1\end{array}$ & 3.85 \\
\hline
\end{tabular}

TABLE III

Results Of The ANTIMICRobial Activity Of The Polyphenol EXTRACt OF THE STEMS INULA VISCOSE

\begin{tabular}{c|c|c|c}
\hline Microbial strain & $\begin{array}{c}\text { Average } \\
(\mathrm{mm})\end{array}$ & $\begin{array}{c}\text { Area } \\
\left(\mathrm{mm}^{2}\right)\end{array}$ & $\begin{array}{c}\text { Coefficient } \\
\text { inhibition }\end{array}$ \\
\hline Escherichia coli & $0 \pm 0$ & 0 & 0 \\
\hline Bacillus thuringiensis & $0.66 \pm 1.45$ & 178.49 & 1.78 \\
\hline Pseudomonas aeruginosa & $0 \pm 0$ & 0 & 0 \\
\hline Micrococcus sp. & $9.33 \pm 0.33$ & 136.73 & 1.36 \\
\hline Salmonelle enterica & $0 \pm 0$ & 0 & 0 \\
\hline Staphylococcus aureus & $14.33 \pm 0.66$ & 322.56 & 322 \\
\hline Enterobacter sp. & $12.33 \pm 1.45$ & 238.88 & 238 \\
\hline Klebsiella pneumoniae & $9.33 \pm 0.88$ & 136.73 & 1.36 \\
\hline Aspergillus niger & $0 \pm 0$ & 0 & 0 \\
\hline Candida albicans & $8 \pm 1$ & 100.53 & 1.00 \\
\hline
\end{tabular}

Depending on the diameter observed, the antimicrobial activity of polyphenols extracted from the stems of Inula viscosa depends on the strain tested. It turned out that this extract has antimicrobial effect on Staphylococcus aureus means $(14.33 \pm 0.66 \mathrm{~mm})$, Enterobacter sp. $(12.33 \pm 1.45 \mathrm{~mm})$, Bacillus thuringiensis $(10.66 \pm 1.45 \mathrm{~mm})$; Micrococcus sp. $(9.33 \pm 0.33 \mathrm{~mm})$, Klebsiella pnoumoniae $(9.33 \pm 0.88 \mathrm{~mm})$ and Candida albicans ( $8 \pm 1 \mathrm{~mm}$ ) which allowed us to infer that these bacteria are sensitive against strains of Escherichia coli $(0 \pm 0)$ Pseudomonas aeruginosa $(0 \pm 0)$ Salmonella enterica $(0 \pm 0)$ and Aspergillus niger $(0 \pm 0)$ are resistant (Fig. 3). However the results of this study are similar to the work of [11]. on Staphylococcus aureus, Escherichia coli and Psendomonas aeroginosa showing the sensitivity of the latter strains with extracts of polyphenols. By elsewhere in 1998, [12] noted a bacterial sensitivity was assessed at $90 \%$. A light of these results, we can say that the antibacterial and antifungal effects achieved are due to the action of polyphenols which is at the aerial parts of the plant. [13and14] reported that polyphenols, such as flavonoids are significant antibacterial property substances [13 and 14]. Thus the results of this study are in agreement with those of [15] the author confirms that the $\mathrm{Gram}^{+}$bacteria are more susceptible than gram ${ }^{-}$bacteria. According to the results, regardless we see the nature of the extract or concentration, Gram $^{-}$bacteria have a strong resistance. This resistance is not surprising; it is related to the nature of their outer membrane which is impermeable to most biocides [16].

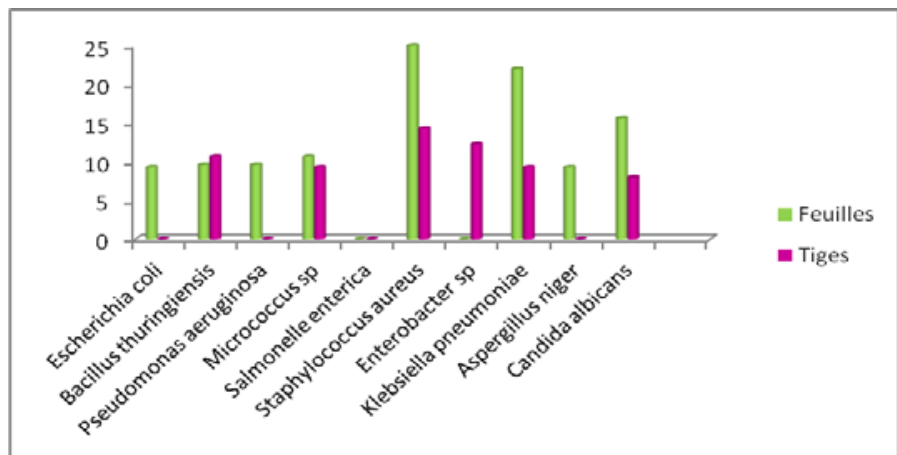

Fig. 3 : Comparing the antimicrobial activity of the leaves and stems

\section{CONCLUSION}

Upon completion of this work, it appears that Inula viscose is a medicinal plant which develops many of medicinal substances like polyphenols located in the stems and leaves. It is very desirable to the extraction of polyphenols in other organ of the plant, and to complete this study by other biological aspect.

\section{REFERENCES}

[1] N. Maurice "De l'herboristerie d'autant à la phytothérapie moléculaire du XX ${ }^{\text {ieme }}$ siècle”. Ed. Lavoisier. Paris, 12 p. 1997.

[2] J. Brunton, "Pharmacognosie : Phytochimie, Plantes Médicinales". $3^{\text {ème }}$ édition Lavoisier Techniques \& Documentation, Paris, Pp. 263-491. 1999.

[3] P. Iserin "Encyclopedia des plantes médicinales ”. Larousse. 321 p. 2001

[4] P. Quezel and S. Santa. "Nouvelle flore de l'Algérie et des régions désertiques Méridionales. Centre national de la recherche scientifique ”,. Tome 2. Pp. 218-940. 1963.

[5] S. Benayache, F. Banayache, I.H. Dendough, and M. Jay. "Les Flavonoïdes de Inula viscosa L. Plantes médicinales et phytotherapie”,.Tome 25, n 4. Pp. 170-176. 1991.

[6] P. Ribereau-Gayon. "Les composes phénoliques des végétaux",. Ed. Dunaud, Paris. 254 p. 1964.

[7] D. Cavalloj, H. Chardon, Chidias, C. Choutet et P. Courvalinp. "Communiqué de la comité Française de l'Antibiogramme". $2^{\text {eme }}$ Ed. Société Française de Microbiologie, Pp. 65-145. 2006.

[8] J. Smadja. "In Essential oils and aromas green. Extraction and application”, (Ed. F. Chemat), Har Krishan Bhalla and sons, Dehradun, Pp. 122-146. 2009

[9] H.H. Lee, L.L. Yang, C.C. Wang, S.Y. Hu, S.F. Chang, and Y.H. Lee. "Differential effects of natural polyphenols on neuronal survival in primary cultured central neurons against glutamate- and glucose deprivation-induced neuronal death “. Brain Research : Pp. 103-113. 2003

http://dx.doi.org/10.1016/S0006-8993(03)03197-4

[10] S. Athamena, I. Chalghem, A. Kassah-Laouar , S. Laroui et S. Khebri. “ activite anti-oxydante et antimicrobienne d'extraits de Cuminum cyminum L.“, Lebanese Science Journal, Vol. 11, n 1.1, 2010.

[11] Y. Hamdi Pacha, M. Benazzouz, H Belkhiri, Z., M. Chari Serakta et L. Bensgni "Effet cicatrisant de Lawsonia inermis L. (Henné) cas des 
brûlures de $3^{\text {ème }}$ degré“‘. Revue Méd. Pharm. Afr., 11-12: Pp. 151-155. 1997.

[12] S.S. Ali, N. Kasoju, A. Luthra, A. Singh, H. Sharana, A. Basava, Sahu, and U. Bora, "Indian médicinal herbs as sources of antioxydants“.Food Res Int, 41: Pp.1-15. 2008. http://dx.doi.org/10.1016/j.foodres.2007.10.001

[13] B. Shan, Y.Z. Cai, J.D. Brooks and H. Corke "The in vitro antibacterial activity of dietary spice and medicinal herb extracts. “, International $J$ Food Microbiology, Pp. 112-117. 2007. http://dx.doi.org/10.1016/j.ijfoodmicro.2007.03.003

[14] T. Askun, G. Tumen, , F. Satil, and M. Ates "In vitro activity of methanol extracts of plants used as spices against Mycobacterium tuberculosis and other bacteria “, Food Chem 116: Pp. 289-294. 2009. http://dx.doi.org/10.1016/j.foodchem.2009.02.048

[15] Z. Mohammedi : "Etude du pouvoir antimicrobien et antioxydant des huiles essentielles et flavonoïdes de quelques plantes de la région de Tlemcen ", , Thèse de magister, Univ. Abou Bekr Belkaid Tlemcen. 2006.

[16] J.L. Fauchere, et J. L. Avril. "Bactériologie générale et médicale“. Ed. Ellipses.Tome 1 Paris, 214 p. 2002. 